
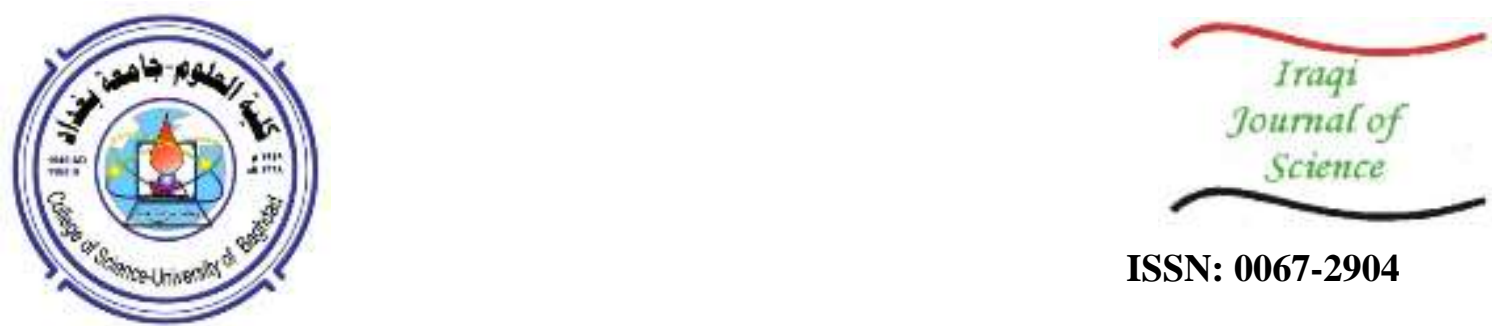

ISSN: 0067-2904

\title{
Extraction and Purification of Lipases Enzyme from Germinating Seeds of Four Crops
}

\author{
Alaa M. Dh. Al-Haidari ${ }^{* 1}$, Saad H. Khudhair ${ }^{2}$, Ibrahim S. Alsaadawi \\ ${ }^{1}$ Department of Biology, College of Science, Baghdad University, Bagdad, Iraq \\ ${ }^{2} \mathrm{Al}$ Karkh University of Science, Baghdad, Iraq
}

Received: 25/8/2019

Accepted: 17/12/2019

\begin{abstract}
Lipase enzyme has attracted a lot of attention in recent years because of its diverse biotechnological applications. The present study was conducted to screen germinated seeds of four crops, namely sunflower (Helianthus annuus), flaxor linseed (Linum usitatissimum ), peanut (Arachis hypogaea ) and castor bean (Ricinus communis), for the activity of their lipases. to the study also included the extraction and purification of lipase from the seeds of the most promising crop using different solvents.

The results indicated that the maximum enzymatic activity $(0.669 \mathrm{U} / \mathrm{ml})$ was obtained when $0.1 \mathrm{M}$ Tris- $\mathrm{HCl}$ buffer extract was used after 3 days of seed germination of all the tested species, as compared to the other test solvents (acetone and water). Sunflower germinated seeds showed the highest lipase activity, which was higher by $159.67,185.32$, and $285.90 \%$ over the activities of castor bean, flax, and peanut seeds, respectively. Among the used ranges of saturation of ammonium sulfate, the ratio of $70 \%$ was the best in precipitating the crude enzyme, showing a highest specific activity of $2.576 \mathrm{U} / \mathrm{mg}$ protein.

The first stage of gel filtration chromatography column by Sephadex G-200 indicated the presence of two non-identical peaks, one for protein and another for lipase activity, between the fractions of 18 to 23 . The active fractions were pooled and loaded again in the Sephadex G-200 column and the eluted fractions showed two identical peaks, one for protein and another for lipase activity, between the fractions of 19 to 23 . The final purification step by gel filtration showed a specific activity of $6.482 \mathrm{U} / \mathrm{mg}$ proteins with a yield of $38.75 \%$ and 11.33 folds of time of purification. The study revealed that sunflower seeds are a better source of lipase as compared to the other used plant seeds, which can be used in different industries.
\end{abstract}

Keywords: Lipase, Extraction, Purification, Different types of plant seeds.

$$
\begin{aligned}
& \text { استخلاص وتتقية انزيمات اللايبيز من البذور النامية لأربعة محاصيل زراعية } \\
& \text { الاء محمد ظافر الحيدري* , سعد حسين خضير², ابراهيم شعبان السعداوي1 } 1 \\
& \text { 1 قسم علوم الحياة، كلية العلوم، جامعة بغداد، بغداد، العراق. } \\
& \text { جامعة الكرخ للعلوم، بغداد، العراق. }
\end{aligned}
$$

*Email: alaadhafer2015@gmail.com 


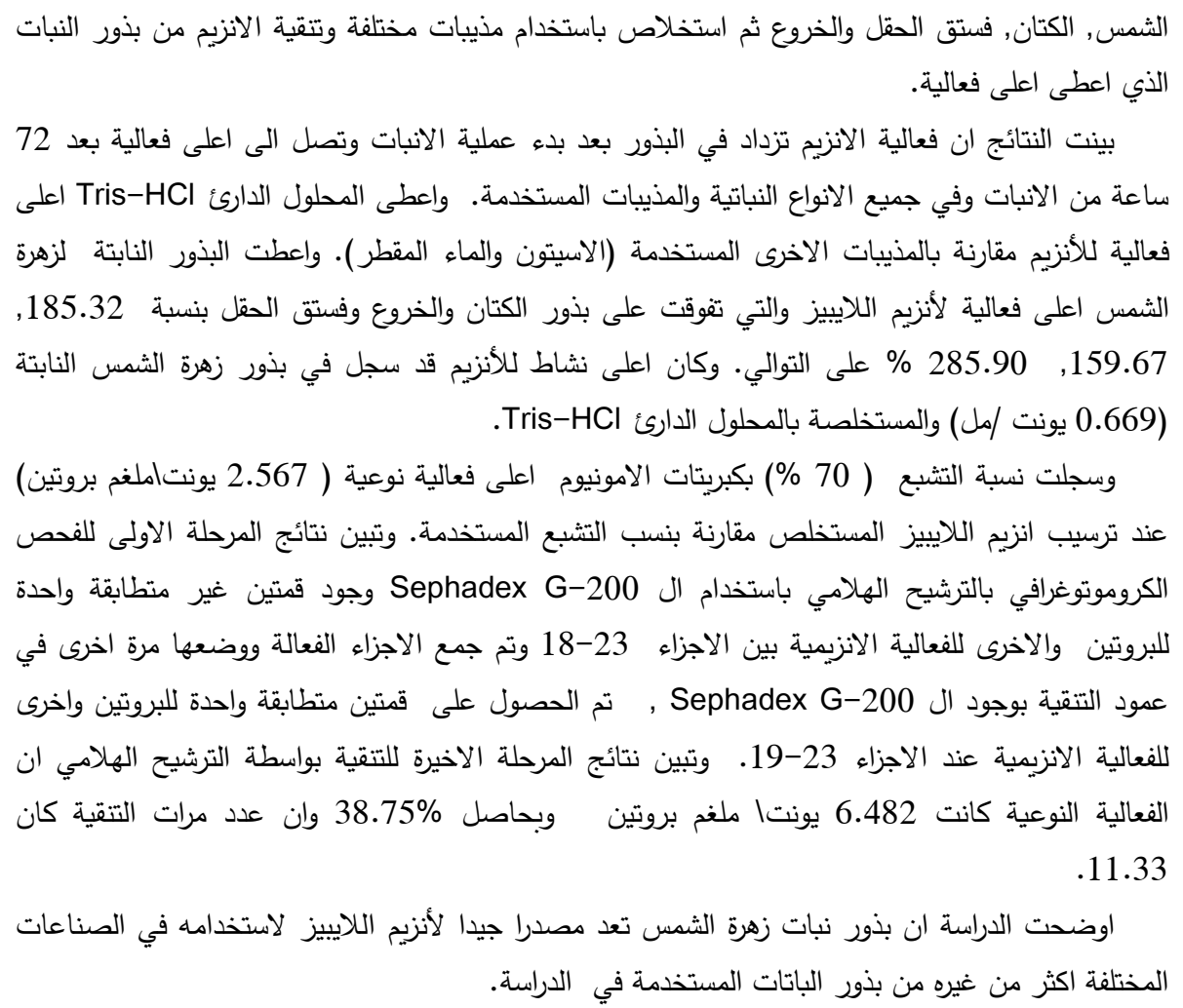

\section{Introduction}

Lipases (triacylglycerol ester hydrolase, EC3.1.1.3) are enzymes that catalyze the total or partial hydrolysis of fats and oils, releasing free fatty acids, diacylglycerol, monoglycerol and glycerol [1]. The purified enzyme is used in a wide range of food industries [2], detergent industries [3], personal care products and cosmetics industries [4]. Also, It is used in biodiesel production [5], pharmaceutical industry [6], polyesters industry [7] and fatty acids production [8].

Lipases can be extracted from microorganisms, including bacteria [9] and fungi [10], and from animals [11] and plants [12,13]. Plant lipases are extracted from different parts of the plant, such as fruits, latex and seeds. However, seeds, especially oil-seeds, are the main parts which contain higher concentrations of lipases. The lipases in seeds play an important role in the growth of the embryo, providing it with energy for growth and development. Therefore, lipases are present in higher levels during the period of seeds germination [14].

Many researches reported that lipases activities in plants are varied according to the species under study and the condition of extraction; therefore, the screening process and the determination of the optimum conditions of extraction are essential steps for the selection of plant species with the higher activity of lipases $[15,16]$.

The present study was conducted to screen seeds of different crops, namely sunflower (Helianthus annuus), flax (Linum usitatissimum), peanut (Arachis hypogaea ) and castor bean (Ricinus communis) for their lipase activities. We also determined the best solvent for extraction and selected the most promising species to purify its lipase and study its characteristics.

\section{Materials and Methods}

\section{Seeds collection and germination}

Seeds of four plant species were obtained from the Directorate of Seeds Certificate, Abu-Ghariab, Baghdad. Uniform and healthy looking seeds were taken from each plant species, soaked separately in distilled water for six hours, placed on moist filter paper inside Petri dishes and allowed to germinate for $24,48,72,96$ and $120 \mathrm{~h}$ under dark condition at room temperature $\left(28 \pm 2^{\circ} \mathrm{C}\right)$. The emergence of radicles was considered as an indication of germination.

\section{Lipase extraction}

Seed coats were removed from the germinated seeds and $20 \mathrm{~g}$ of fresh weight of cotyledons at each germination time were separately homogenized for 5 minutes with $80 \mathrm{ml}$ of Tris- $\mathrm{HCl}$ buffer $(0.1 \mathrm{M}, \mathrm{pH}=7.5)$, distilled water (DW), and cold acetone solvents. The extracts of Tris- $\mathrm{HCl}$ buffer 
and DW were filtered through four layers of cheese cloth and centrifuged at $10000 \mathrm{rpm}$ using cooling centrifuge $\left(4^{\circ} \mathrm{C}\right)$ for 30 minutes. The upper fat layer was removed by a spatula and the supernatant was taken as a source of crude lipases [12].

For lipase extraction by acetone, the homogenized extract was centrifuged at $3000 \mathrm{rpm}$ using cooling centrifuge at $4{ }^{\circ} \mathrm{C}$ for $30 \mathrm{~min}$. The pellet obtained was dissolved in $100 \mathrm{ml}$ of DW then centrifuged at $7500 \mathrm{rpm}$. The supernatant was obtained as a source of crude lipase [16].

\section{Assay of lipases activity at different germination times}

Lipase activity in the extract of each plant species was determined according to Rahman et al. [17]. The reaction mixture consisted of $1 \mathrm{ml}$ of crude enzyme and $2.5 \mathrm{ml}$ of olive oil emulsion $(10 \mathrm{~g}$ of each of olive oil and Arabic gum was mixed with $200 \mathrm{ml}$ of $0.1 \mathrm{M}$ Tris- $\mathrm{HCl}$ buffer, $\mathrm{pH}=7.5$ and homogenized by vortex for $10 \mathrm{~min}$.). A volume of $0.02 \mathrm{ml}$ of $20 \mathrm{mmol} \mathrm{CaCl}_{2} .2 \mathrm{H}_{2} \mathrm{O}$ was added to the mixture and shaken at $150 \mathrm{rpm}$ by a shaking water path for $20 \mathrm{~min}$ at $30{ }^{\circ} \mathrm{C}$. The reaction was stopped by adding $5 \mathrm{ml}$ of isooctane and $1 \mathrm{ml}$ of $6 \mathrm{~N} \mathrm{HCl}$. The upper layer (about $4 \mathrm{ml}$ ) was taken in another test tube and $1 \mathrm{ml}$ of the reagent (5\% cupric acetate/ pyridine) was added. The free fatty acids were determined by using a spectrophotometer at $715 \mathrm{~nm}$. A standard curve of oleic acid was made to determine the lipase activity according to the amount of free fatty acids. The amount of lipase enzyme that liberated $1 \mu \mathrm{mol}$ free fatty acids in $1 \mathrm{~min}$ at $30^{\circ} \mathrm{C}$ was defined as one unit of lipase enzyme activity [17].

Based on the results of the previous experiments, the highest lipases activity appeared in seeds of all test plants at $72 \mathrm{~h}$ after sowing and started to slightly decrease thereafter; also, the seeds of sunflower showed the highest lipase activity as compared to the other plant species. Therefore, all the subsequent experiments of purification, characterization, and application were carried out on sunflower lipases.

\section{Protein estimation}

Lowry's method [18] was used to determine protein concentration of the enzyme supernatants using a standard curve of Bovine Serum Albumin (BSA) at $1 \mathrm{mg} / \mathrm{ml}$. Different concentrations (0- 100 $\mu \mathrm{g} / \mathrm{ml}$ ) of BSA were prepared and the absorbance was read at $600 \mathrm{~nm}$ to obtain the standard curve. The concentration of protein in the extract of sunflower seeds was estimated from the standard curve.

\section{Purification of Sunflower lipases \\ Ammonium sulfate precipitation and dialysis}

For the purification step, ammonium sulfate, which is required to precipitate the lipase enzyme, was optimized by adding it at varying concentrations of saturation $(40 \%, 50 \%, 60 \%, 70 \%$ and $80 \%)$ to the crude extract of lipases [19].

Ammonium sulfate was slowly added, initially at $40 \%$ saturation, to precipitate the protein while being kept in ice with gentle stirring. The precipitate protein was obtained by centrifuging the $40 \%$ saturation solution at $10000 \mathrm{rpm}$ for $15 \mathrm{~min}$ at $4{ }^{\circ} \mathrm{C}$. The precipitated protein was re-suspended in $0.1 \mathrm{M}$ Tris- $\mathrm{HCl}$ buffer $(\mathrm{pH}=7.5)$ and dialyzed overnight against the same buffer [16]. The process was repeated similarly with the other test concentrations of ammonium sulfate to find out the most efficient salt concentration required for protein precipitation.

\section{Gel filtration chromatography}

The partially purified enzyme from the ammonium precipitation step was further purified by gel filtration chromatography using Sephadex G-200 column $(2.5 \times 30 \mathrm{~cm})$ and Tris-HCl buffer $(0.1 \mathrm{M}$, $\mathrm{pH}=7.5$ ) for elution. The fractions (each of about $3 \mathrm{ml}$ ) were collected to determine protein concentration using a spectrophotometer at $280 \mathrm{~nm}$ and the enzyme activity of each fraction was determined by the above mentioned method [20].

The fractions that demonstrated the highest enzyme activity were pooled together and used for another purification step by gel filtration against Sephadex G-200 column. The fractions of the second purification step were used to measure the enzyme activity, as in the above mentioned method, and protein concentration at $280 \mathrm{~nm}$ using a spectrophotometer [20].

\section{Results and discussion}

\section{Extraction of lipase}

The results showed that all the germinated seeds demonstrated the highest enzyme activity after 3 days (72 h.) of germination time. The maximum lipase activity was recorded by sunflower $(0.669 \mathrm{U} / \mathrm{ml})$, which was higher than those of castor bean, flax and peanut seeds by 159.67, 185.32 and $285.90 \%$, respectively, as shown in Figure-1. 


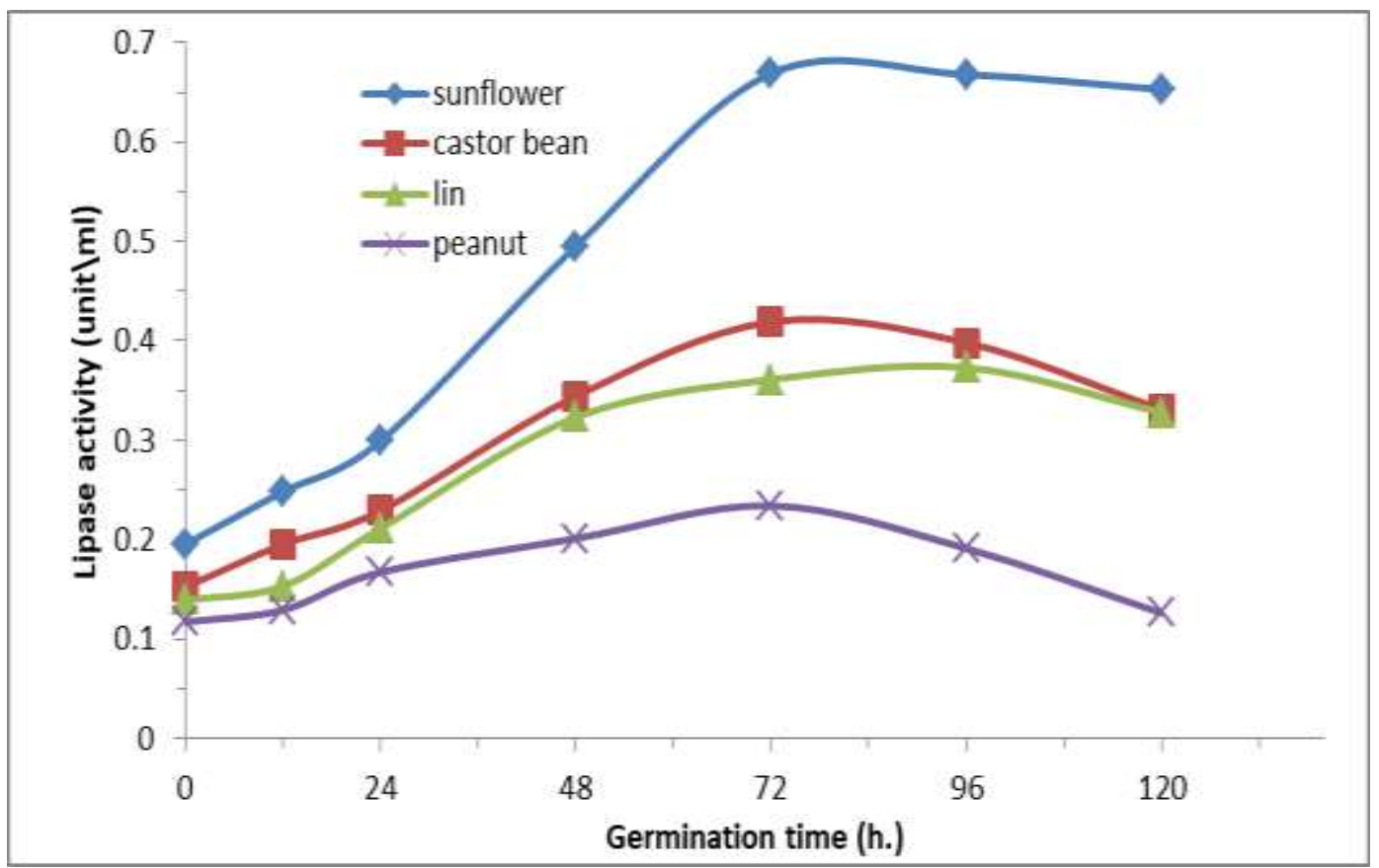

Figure 1-Lipases activity at different germination times of test crop seeds. The seeds at zero time were soaked for $6 \mathrm{~h}$ before extraction.

The results in Table- 1 revealed that the $0.1 \mathrm{M}$ Tris- $\mathrm{HCl}$ buffer, $\mathrm{pH}=7.5$, exhibited the best ability to extract lipase compared with the other solvents. Moreover, sunflower seeds also produced the maximum levels of lipase enzyme $(0.669,0.520$ and $0.427 \mathrm{U} / \mathrm{ml})$ when extracted by Tris- $\mathrm{HCl}$ buffer, acetone and DW, respectively, compared with the other used seeds.

Table 1- Lipases activity in germinated the seeds of different crops as extracted by different solvents.

\begin{tabular}{|c|c|c|c|c|}
\hline \multirow{2}{*}{ Seeds of Plant species } & \multicolumn{4}{|c|}{ Lipases activity $(\mathrm{U} / \mathrm{ml})^{*}$} \\
\cline { 2 - 5 } & \multicolumn{4}{|c|}{ Solvent of extraction } \\
\cline { 2 - 5 } & Tris- HCl buffer & Distilled water & Acetone & Average \\
\hline sunflower & 0.669 & 0.427 & 0.520 & 0.535 \\
\hline flax & 0.361 & 0.281 & 0.160 & 0.276 \\
\hline peanut & 0.234 & 0.161 & 0.089 & 0.161 \\
\hline castor bean & 0.419 & 0.094 & 0.384 & 0.352 \\
\hline Average & 0.417 & 0.240 & 0.163 & \\
\hline LSD P $\leq 0.05$ & $\mathrm{P}=0.05$ & $\mathrm{~S}=0.05$ & $\mathrm{P} \times \mathrm{S}=0.09$ & \\
\hline
\end{tabular}

* Enzyme activity was determined at $72 \mathrm{~h}$. after seed germination.

Various previous studies described the extraction of lipase from different plant seeds at different germination times with different solvents. Sammour [21] extracted lipase from germinated linseeds every $12 \mathrm{~h}$ for 5 continuous days with $165 \mathrm{mM}$ tricine- $\mathrm{NaOH}$ buffer $(\mathrm{pH}$ 7.5) and cold grinding medium consisting of $0.4 \mathrm{M}$ sucrose, $10 \mathrm{mM} \mathrm{KCl}, 2 \mathrm{mM}$ EDTA, $2 \mathrm{mM}$ dithiothreitol, and $1 \mathrm{mM}$ $\mathrm{MgCl} 2$ ). His results showed that the highest lipase activity was obtained after $72 \mathrm{~h}$. of seeds germination and remained constant at 84 and $96 \mathrm{~h}$..

Another study by Ezema [20] extracted lipase from four days-germinated seeds of Cucumeropsis mannii with two separated buffers $(150 \mathrm{mM}$ Tris- $\mathrm{HCl}$ buffer, $\mathrm{pH}=7.5$, and $150 \mathrm{mM}$ phosphate buffer, $\mathrm{pH}=5.9)$ and a cold grinding medium containing $0.4 \mathrm{M}$ sucrose, $0.5 \mathrm{mM}$ EDTA, $2.0 \mathrm{mM} \beta-$ mercaptoethanol, and $1.95 \%(\mathrm{w} / \mathrm{v})$ Tween 80 . Okunwaye et al. [12] used Tris- $\mathrm{HCl}$ buffer as a solvent during lipase extraction from the fruit mesocarp of Raphia palm, which demonstrated the highest value of lipase activity $(23.05 \mathrm{U} / \mathrm{ml})$.,

\section{Purification of lipase}

The crude lipase was extracted by Tris- $\mathrm{HCl}$ buffer from sunflower germinated seeds which were 
subjected to a purification protocol. The purification involved ammonium sulfate precipitation followed by two steps of gel filtration by Sephadex G-200 column, as in Table-3. Table-2 shows the results of crude enzyme precipitation in different saturation ranges of ammonium sulfate. The highest enzymatic activity was observed in the ratio of $60-80 \%$ ammonium sulfate compared with the other used ratios. Also, the results revealed that $70 \%$ ammonium sulfate demonstrated the best specific activity (2.576 U/mg protein) with a yield of $69.21 \%$.

Table 2-Lipases precipitation by different concentrations of ammonium sulfate

\begin{tabular}{cccccccc}
\hline $\begin{array}{c}\text { Purification } \\
\text { Steps }\end{array}$ & $\begin{array}{c}\text { Volume } \\
(\mathrm{ml})\end{array}$ & $\begin{array}{c}\text { Activity } \\
(\mathrm{U} / \mathrm{ml})\end{array}$ & $\begin{array}{c}\text { Total } \\
\text { activity } \\
(\mathrm{U})\end{array}$ & $\begin{array}{c}\text { Protein } \\
\text { concentration } \\
(\mathrm{mg} / \mathrm{ml})\end{array}$ & $\begin{array}{c}\text { Total } \\
\text { protein } \\
(\mathrm{mg})\end{array}$ & $\begin{array}{c}\text { Specific } \\
\text { activity } \\
(\mathrm{U} / \mathrm{mg})\end{array}$ & $\begin{array}{c}\text { Yield } \\
(\%)\end{array}$ \\
\hline $\begin{array}{c}\text { Crude } \\
\text { enzyme }\end{array}$ & 31 & 0.885 & 27.435 & 1.601 & 49.631 & 0.552 & 100.00 \\
$40 \%$ & 8 & 0.362 & 2.896 & 0.509 & 4.072 & 0.711 & 10.55 \\
$50 \%$ & 8 & 0.637 & 5.384 & 0.691 & 5.528 & 0.973 & 19.62 \\
$60 \%$ & 8 & 1.215 & 9.720 & 0.811 & 6.488 & 1.498 & 35.42 \\
$70 \%$ & 8 & 2.373 & 18.99 & 0.921 & 7.368 & 2.576 & 69.21 \\
$80 \%$ & 8 & 2.400 & 19.21 & 1.330 & 10.46 & 1.805 & 70.02 \\
\hline
\end{tabular}

Other studies found that using $80 \%$ ammonium sulfate is the best to precipitate the crude lipases [12]. Madhikar et al. [16] used 80\% of ammonium sulfate saturation for protein precipitating from sunflower seeds. Ammonium sulfate was reported to be an appropriate salt because it is highly soluble in water and a cheap chemical material compared with other salts [22]. Nevertheless, other researchers used other compounds in the precipitation process, such as Eze and Ezema [23] who used ammonium sulfate and cold acetone for protein precipitation. One half of the crude extract of white melon seeds was precipitated with ammonium sulfate at $70 \%$ saturation, whereas the second half of the crude was saturated with cold acetone at $50 \%(\mathrm{v} / \mathrm{v})$.

The enzyme obtained from $70 \%$ ammonium sulfate precipitation was again purified by gel filtration chromatography column, as in Figure-2. The results indicated the presence of two protein peaks with only one peak of lipase activity between the fractions of 18 to 23 .

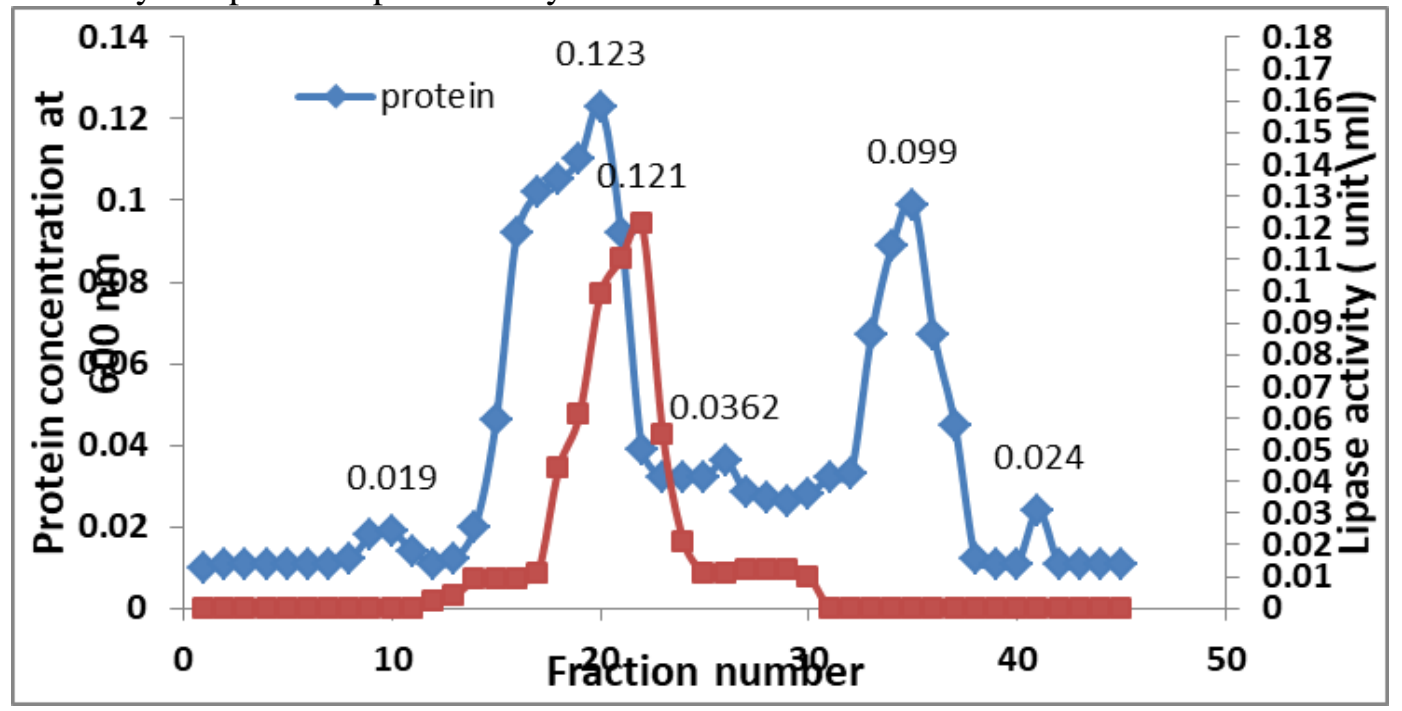

Figure 2-The first step of lipase purification using Sephadex G-200 gel filtration column chromatography.

The active fractions from the first step of gel filtration were again pooled and loaded into the Sephadex G-200 column.

The results in Figure-3 revealed the presence of two identical peaks for protein and enzyme activities, which is a good indicator on the purification steps. Also, the active fractions for the enzymatic activity were found between the fractions of 19 to 23 . 


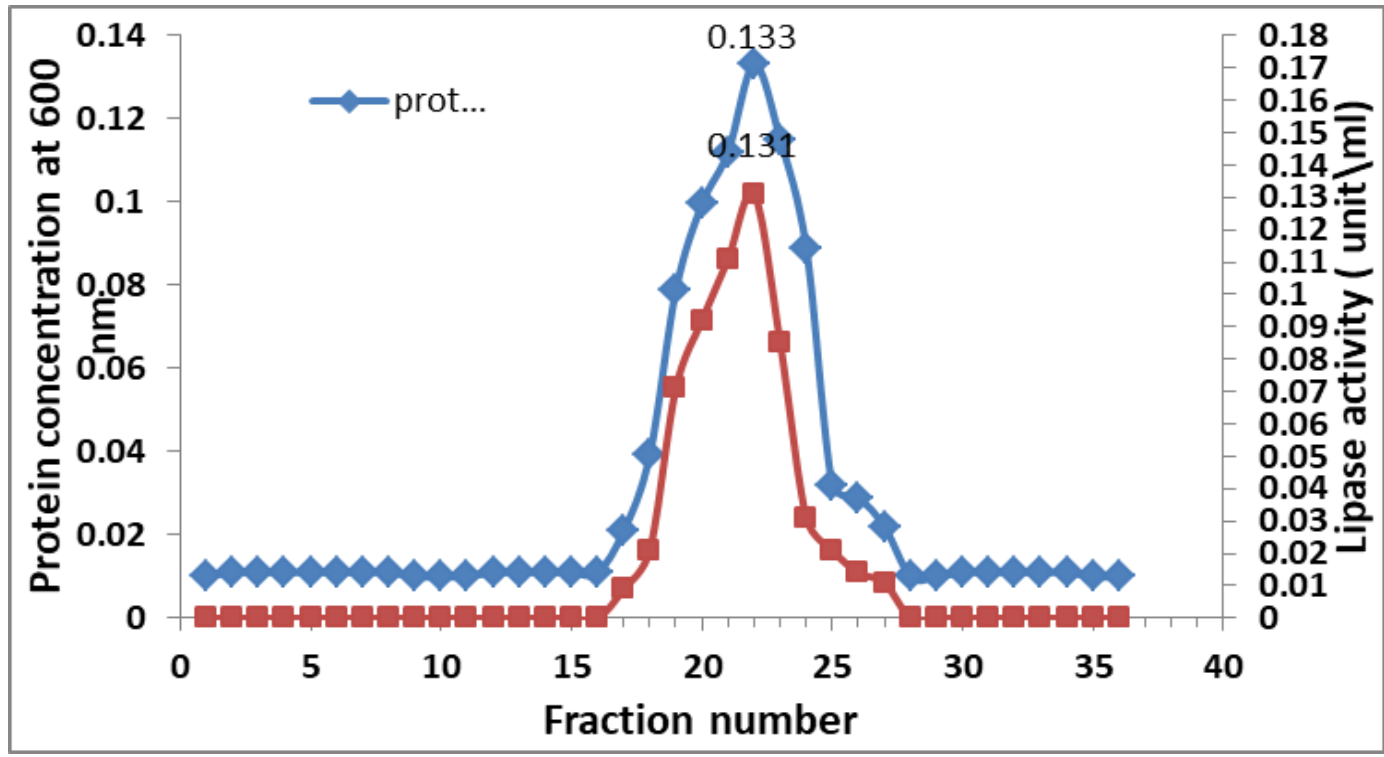

Figure 3-The second step of lipase purification using Sephadex G-200 gel filtration column chromatography.

Further results can be concluded from Table-3, which shows the results of the final purification. The first and second stages of the gel filtration column demonstrated the maximum specific activity (4.644 and $6.482 \mathrm{U} / \mathrm{mg}$ protein) with purification fold that reached to 8.12 and 11.33 times, respectively.

Table 3-Purification steps of lipases enzyme extracted from sunflower seeds.

\begin{tabular}{ccccccccc}
\hline $\begin{array}{c}\text { Purification } \\
\text { Steps }\end{array}$ & $\begin{array}{c}\text { Volume } \\
(\mathrm{ml})\end{array}$ & $\begin{array}{c}\text { Activity } \\
(\mathrm{U} / \mathrm{ml})\end{array}$ & $\begin{array}{c}\text { Total } \\
\text { activity } \\
(\mathrm{U})\end{array}$ & $\begin{array}{c}\text { Protein } \\
\text { concentration } \\
(\mathrm{mg} / \mathrm{ml})\end{array}$ & $\begin{array}{c}\text { Total } \\
\text { protein } \\
(\mathrm{mg})\end{array}$ & $\begin{array}{c}\text { Specific } \\
\text { Activity } \\
(\mathrm{U} / \mathrm{mg})\end{array}$ & $\begin{array}{c}\text { Purification } \\
\text { Fold }\end{array}$ & $\begin{array}{c}\text { Yield } \\
(\%)\end{array}$ \\
\hline $\begin{array}{c}\text { Crude } \\
\text { enzyme }\end{array}$ & 50 & 0.562 & 28.100 & 0.982 & 49.100 & 0.572 & 1.00 & 100.00 \\
$\begin{array}{c}70 \% \text { of } \\
\left(\mathrm{NH}_{4}\right)_{2} \mathrm{SO}_{4}\end{array}$ & 11 & 1.825 & 20.075 & 0.724 & 7.964 & 2.520 & 4.40 & 71.44 \\
$\begin{array}{c}\text { Chromatography } \\
\text { on Sephadex G- } \\
\text { 200 (first step) }\end{array}$ & 18 & 0.692 & 12.456 & 0.149 & 2.682 & 4.644 & 8.12 & 44.32 \\
$\begin{array}{c}\text { Chromatography } \\
\text { on Sephadex G- } \\
\text { 200 (second } \\
\text { step) }\end{array}$ & 15 & 0.726 & 10.890 & 0.112 & 1.680 & 6.482 & 11.33 & 38.75 \\
\hline
\end{tabular}

These results showed that the optimum activity was obtained from the lipase enzyme extracted from sunflower seeds using Tris-HCl buffer and then purified in two steps by gel filtration. The extracted enzyme can be employed in different industrial applications.

\section{References}

1. Villeneuve, P., Muderhwa, J.M., Graille, J. and Haas, M.J. 2000. Custamizing lipases for biocatalysis: A survey of chemical, physical and molecular biological approaches, J. of Molecular catalysis B: Enzymetic, 9: 113-148.

2. Nagodawithana, T. and Reed, G. 1993. Enzymes in food processing. $3^{\text {rd }}$ edition. Academic press, San Diego, USA.

3. Wiseman, A. 1995. Introduction to principles. In Handbook of Enzyme Biotechnology. T.J. Press Ltd. Padstow, Cornwall, UK.

4. Matzger, J. O. and Bornscheuer, U. 2006. Lipids as renewable resources: current state of chemical and biotechnological conversion and diversification. Applied Microbial Biotechnology, 71: 13-22. 
5. Gashaw, A., Getachew, T., and Teshita, A. 2015. A Review on biodiesel production as alternative fuel. J. For. Prod. Ind. 4: 80-85.

6. Cancino, M., Bauchart, P., Sandoval, G., Nicaud, J.M., Ander, I., Dossat, V. and Marty, A. 2008. A variant of Yarrowinia lipolytica lipase with improved activity and enantio-selectivity for resolution of 2-bromoarylacetic acid esters. Tetrahed Asymmet, 19: 1608-1612.

7. Kumar, A. and Gross, R.A. 2000. Candida antractica Lipase $\beta$ catalyzed trans-esterification: new synthetic routes to copolymes. J. Am. Chem. Soc., 122: 176-177.

8. Linder, M., Matooba, E., Fanni, J. and Parmentier, M. 2002. Enrichment of salmon oil with n-3 PUFA by lipolysis, filtration and enzymatic re-esterification. Eur. J. Lipid Sci. Technol, 104: 455462.

9. Rathi, P., Bradoo, S., Saxena, R. K. and Gupta, R. 2000. A hyper thermostable, alkaline lipase from Pseudomonas sp. with the property of thermal activation. Biotechnol. Lett. 22: 495-498.

10. Ayinla, Z. A., Ademakinwa, A. N. and Agboola, F. K. 2017. Studies on the Optimization of Lipase Production by Rhizopus sp. ZAC3 Isolated from the Contaminated Soil of a Palm Oil Processing Shed. J. of Applied Biology and Biotechnology, 5: 030-037.

11. Osterlund, T. 2001. Structure- function relationships of hormone- sensitive lipase. Eur. $J$. Biochem., 268: 1899- 1907.

12. Okunwaye, T., Obibuzor, J. U. and Okogbenin, E. A. 2015. Purification and biochemical properties of lipase from Raphia palm fruit mesocarp. African Journal of Biochemistry Research, 9: 73- 80.

13.Mazou, M., Djossou, A. J., Tchobo, F. P., Villeneuve, P. and Soumanou, M. M. 2017. Catalytic properties of lipase from Fiicus trichpoda and Euphorbia unispina latex: Study of their typoselectivity. Journal of Applied Biosciences, 110: 10790- 10801.

14. Enujiugha, V. N., Thani, F. A., Sanni, T. M. and Abigor, R. D. 2004. Lipase activity in dormant seeds of the African oil bean (Pentaclethra marcrohylla Benth). Food Chemistry, 88: 405- 509.

15. Bahri, S. 2000. Lipase activity in germinating sunflower seedlings. Biochemical Society Transactions, 28: 771- 773.

16.Madhikar, S.D., Gadge, P.P, Yewle, J.N., Jadhav, U.U., Chougale, A.D., Zambare, V.P. and Paul, M.V. 2011. Isolation, Partial Purification and Characterization of lipase from sunflower germination oil seeds. Int. J. Biotech. Biosci, 1(4): 410-415.

17.Rahman, R., Baharum, S. N., Basri, M. and Salleh, A. B. 2005. High-yield purification of an organic solvent- tolerant lipase from Pseudomonas sp. strain S5. Anal. Biochem. 341: 267-274.

18.Lowry, O. H., Rosebrough, N. J., Farr, A. L. and Randall, R. J. 1951. Protein measurement with the Folin phenol reagent. J. Biochem. 193: 265-275.

19. Kilic, I and Sagiroglu, A. 2012. Hazelnut seed lipase: extraction, purification and characterization. Tarkya Univ. J. Nat. Sci., 13: 15-25.

20. Ezema, B.O. 2012. Purification and characterization of lipase (EC.3.1.1.3) from the seeds of Cucumeropsis mannii (White melon). M.Sc. thesis, department of biochemistry, University of Nigeria, Nsukka.

21.Sammour, R. H. 2005. Purification and partial characterization of an acid lipase in germinating lipidbody linseedlings. Turk. J. Bot. 29: 177- 184.

22. Al- badri, R. H. 2012. Extraction, partial purification and characterization of peroxidase from Malva neglecta. M.Sc. thesis, Biotechnology department, College of Science, University of Baghdad.

23.Eze, S. O. O. and Ezema, B. O. 2012. Purification and characterization of lipase (EC. 3.1.1.3) from the seeds of Cucumeropsis mannii (White melon). Thai. Journal of Agricultural Science. 45: 115120. 